\title{
Shrimp farming: Where does the carbon go?
}

\author{
Leonel da Silveira Lobo Sternberg \\ Department of Biology, University of Miami, \\ Coral Gables, Florida, USA
}

\author{
Carlos Augusto Ramos e Silva \\ Department of Limnology and Oceanography \\ Rio Grande do Norte Federal University \\ Natal, Rio Grande do Norte, Brazil \\ Postgraduate Program in Dynamics of the Earth \\ and Oceans, Fluminense Federal University, \\ Rio de Janeiro, Brazil
}

Pablo Bezerra Dávalos

Postgraduate Program in Dynamics of the Earth

and Oceans, Fluminense Federal University,

Rio de Janeiro, Brazil

\begin{abstract}
The muscle tissues of the Litopenaeus vannamei shrimp grown in ponds through organic and traditional (intensive) management show that $\delta^{13} \mathrm{C}$ values were similar amongst the shrimp. Shrimp grown in the traditional pond were enriched in ${ }^{13} \mathrm{C}$ by $7 \%$ relative to the carbon isotope ratios of their feed. The differences in the carbon isotope ratios of shrimp and feed in the traditional pond shows that the feed is not the main carbon source for shrimp grown in the traditional intensive management. Using mass balance we calculate that feed in traditional culture contributes at most $13 \%$ of the shrimp's carbon biomass.
\end{abstract}

Keywords: feeding, shrimp culture, food, estuaries, stable carbon isotope, organic management

\section{Introduction}

Net profits from shrimp farming can run to billions of U.S. dollars, with Thailand and China being the leading producers, followed by other Asian and Latin American countries (World Bank et al. 2002). The process of establishing and maintaining intensive or organic shrimp farms involves clearing land often populated by mangroves, building shrimp ponds and the associated pumps, feeding and aeration. The environmental impact stemming from the establishment and maintenance of shrimp ponds is tremendous. Feeding, which also exacerbates the environmental impact, is one of the most expensive

Addresses: L. S. L. Sternberg: Coral Gables, Florida 33124-0421, USA, e-mail: leo@bio.miami.edu C. A. R. Silva, P. B. Dávalos: Niterói/RJ, Caixa Postal: 106051, CEP: 24230-971, Brazil.

Received: March 28, 2013; accepted: May 17, 2013 
endeavors during the maintenance of the pond. Feed can vary in composition depending on the industry, some providing a mixture of ground fish meal, others providing terrestrial animal and plant proteins. In addition to causing a significant impact on wild fish stocks, use of feed promotes eutrophication and ensuing anoxic conditions (Primavera 2006). The latter makes it necessary to artificially aerate pond water by agitation with motor-driven paddles. Furthermore, the introduction of feed can promote viral, bacterial and fungal parasites. We show here that organic feeding of shrimp ponds, with its ensuing environmental problems, provides little if any carbon to shrimp biomass.

We measured the stable carbon isotope of shrimp muscle tissue and determined whether it matches that of the feed. Previously it was shown that the average carbon isotope ratios of shrimp tissue (Penaeus aztecus) are within $1 \%$ of the $\delta^{13} \mathrm{C}$ value of its carbon source (Fry and Arnold 1982). We compared the $\delta^{13} \mathrm{C}$ value of shrimp (Litopenaeus vannamei) growing in an organic farm $(\mathrm{O}-\mathrm{F})$, which does not use feed, with a nearby intensive farm (I-F). We also measured carbon isotope ratios of the feed (Naturales Tropical Shrimp, Rio Grande do Norte, Brazil) used in the intensive farm, other potential sources of foods (plankton and polychaetes) and sediment. Carbon isotope data are also presented in another manuscript (in preparation), focusing on the impact of traditional shrimp farming on water quality.

\section{Materials and methods}

Study site

The Guaraira lagoon complex (GUR) lies about $90 \mathrm{~km}$ south of Natal, Brazil $\left(06^{\circ} 05^{\prime} \mathrm{S}\right.$ and $06^{\circ} 15^{\prime} \mathrm{S} ; 35^{\circ} 00^{\prime} \mathrm{W}$ and $35^{\circ} 15^{\prime} \mathrm{W}$ ) (Fig. 1 ). These shallow systems are affected by shrimp farming, agriculture and domestic sewage. Mangrove forests bordering these estuaries have been partially removed to make room for shrimp ponds. Approximately 94,000 people inhabit the surrounding area, which contains 2,874.09 ha of shrimp farms and 16,664 ha of sugar-cane monoculture (IDEMA 2004). The dry season runs from September to December and the rainy season from February to August, but January has had the highest rainfall levels since 2001. The mean annual temperature and annual rainfall are $26.8^{\circ} \mathrm{C}$ and 1,600 $\mathrm{mm}$, respectively (EMPARN 2004).

Management practices are different for each shrimp farm system (intensive and organic), particularly in relation to the stocking densities of Litopenaeus vannamei, crop cycles, feed, and water exchanges (Table 1). The samples were collected in ponds measuring approximately 2 ha. Shrimp farming is distributed along different parts of this estuarine complex (see Fig. 1). 


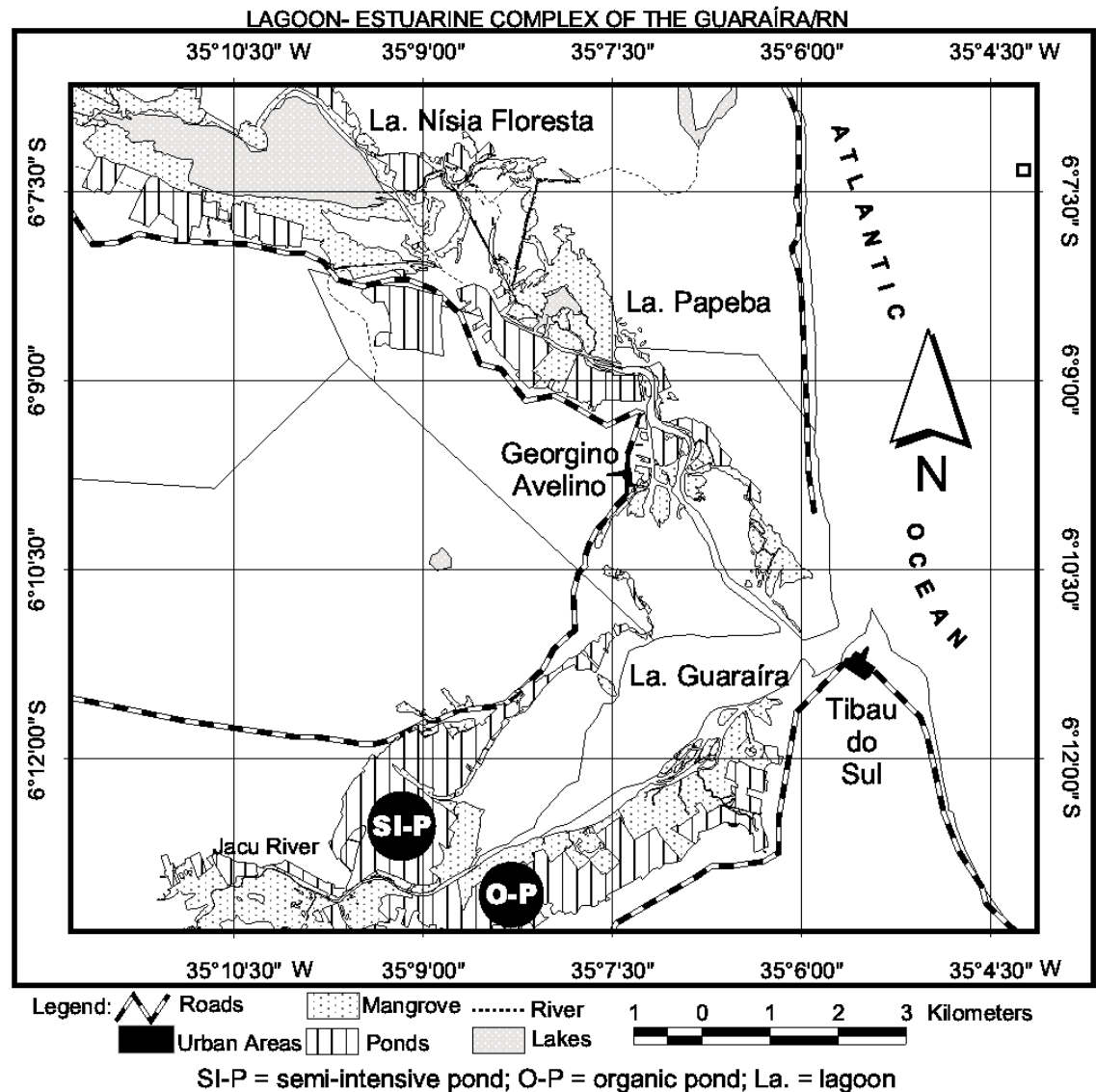

Fig. 1

Map of the shrimp ponds (traditional and organic) located in the eastern region of Rio Grande do Norte state, Brazil

Table 1

Characterization of shrimp farming management

\begin{tabular}{lcc}
\hline Practices & Organic & Intensive \\
\hline Density (shrimp $\left./ \mathrm{m}^{2}\right)$ & 3 & 30 \\
Aeration & No & Yes \\
Crop cycle (days) & 80 & 130 \\
Water exchange per day (\%) & 2 & 5 \\
Nutrition & Natural & Feed \\
Limestone & No & Yes \\
\hline
\end{tabular}


Sampling and analysis protocols

Shrimp samples were collected from two commercial shrimp farms. The organic farm uses low-impact techniques (without the use of artificial feeds), whereas the intensive farm uses conventional intensive methods including the use of organic shrimp feed. From each farm we collected 10 shrimp samples, extracted the muscle tissue dried at $60^{\circ} \mathrm{C}$ for a period of 72 hours, ground into a fine powder and send to the laboratory of Stable Isotope Ecology of Tropical Ecosystem (LSIETE, Dept. of Biology, University of Miami).

During plankton samplings, which took place at each of the above locations, 5 replicates of water samples were collected with "Van Dorn" type bottles, filtered with a porous membrane $(\mathrm{GF} / \mathrm{C})$, the filtrand dried at $60^{\circ} \mathrm{C}$ for 72 hours and sent to LSIETE for isotopic analysis.

Superficial sediment samplings were carried out by sampling 5 replicates of surface sediments at each of the above locations with PVC containers. Samples were subsequently dried at $60^{\circ} \mathrm{C}$ and passed through a sieve to obtain particle sizes below $1 \mathrm{~mm}$. Samples were sent to LSIETE where they were treated with 1 $\mathrm{N} \mathrm{HCl}$ to remove any carbonates.

During polychaete samplings, which took place at each of the above locations, 10 polychaete samples were sampled, muscle tissue dissected out and dried at $60^{\circ} \mathrm{C}$ for 72 hours. Samples were mixed, ground and sent to LSIETE for isotopic analysis.

During isotopic analyses, approximately $1.2 \mathrm{mg}$ of dried samples were packed in small tin containers crushed into a small sphere and inserted in a sampling wheel of an automated elemental analyzer (Eurovector, Milan, Italy) connected to an Isoprime Stable Isotope Mass Spectrometer (Elementar, Hanau, Germany). For the shrimp, polychaete and food analysis were done in duplicate of the merged samples. One analysis was carried out for each plankton replicate collection. Carbon isotope ratios are reported as $\delta^{13} C$ where $\delta^{13} C=\left(R_{\text {sample }} / R_{\text {std }}-1\right)^{*} 1000$. $\mathrm{R}_{\text {sample }}$ and $\mathrm{R}_{\text {std }}$ represent the ${ }^{13} \mathrm{C} /{ }^{12} \mathrm{C}$ ratio of the sample and standard (vPDB), respectively. The precision is $\pm 0.1 \%$.

\section{Results and Discussion}

Intensively farmed shrimp had $\delta^{13} \mathrm{C}$ values similar to the O-F farmed shrimp and was approximately 7\%o more enriched than that of the feed, indicating that artificial feed carbon has little impact, if any, in shrimp carbon biomass (Fig. 2).

We determined the percentage of artificial feed carbon in the shrimp biomass from the intensive farm $(x \%)$ using the average $\delta^{13} \mathrm{C}$ value of O-F shrimps and artificial feed carbon as end members and the following mass balance equation:

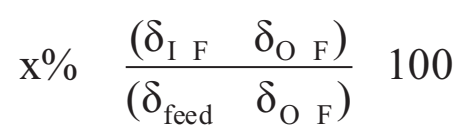


where $\delta_{\mathrm{I}-\mathrm{F}}, \delta_{\mathrm{O}-\mathrm{F}}$ and $\delta_{\text {feed }}$ represent the $\delta^{13} \mathrm{C}$ values of the shrimp from the intensive farm, organic farm and of the artificial feed, respectively. We estimate that the percentage of artificial feed carbon only makes up to $13 \%$ of the shrimp biomass. Others have alluded to the "inefficiency" of artificial feed in shrimp aquacultures in Asian farms as well (World Bank et al. 2002; Burford et al. 2004). Carbon isotope ratios of sediments indicate that the carbon is largely deposited as sediment, leading to significant isotopic depletion in sediment carbon for the intensively farmed shrimp (Fig. 2).

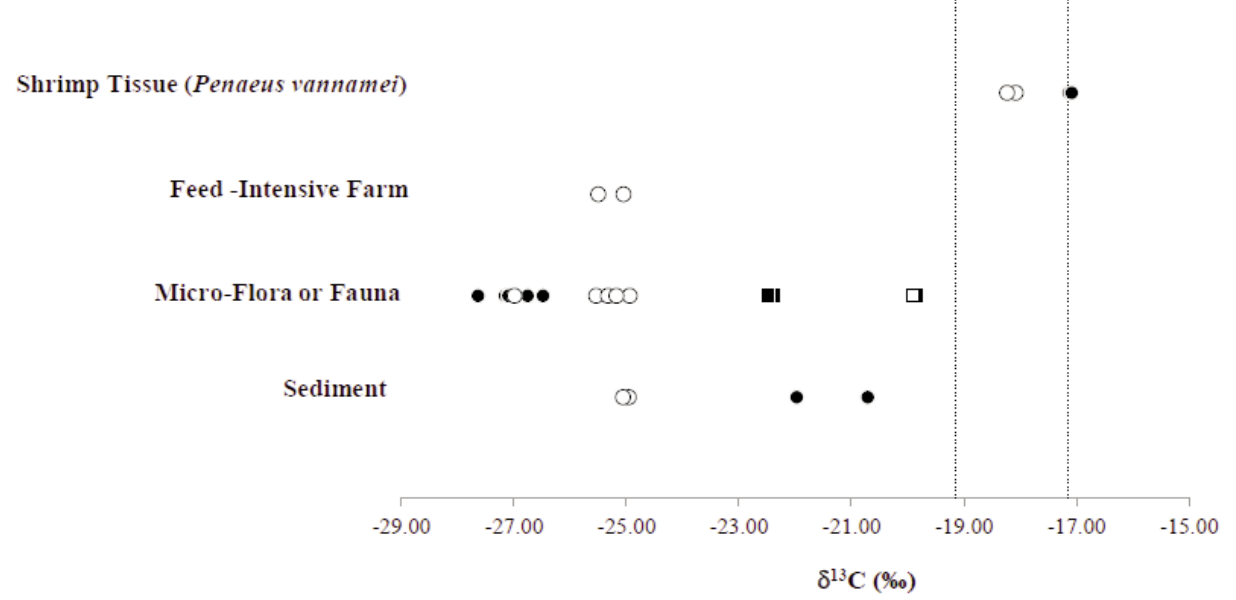

Fig. 2

The $\delta^{13} \mathrm{C}$ values of shrimp tissue, feed, micro-flora and fauna (plankton $(\bullet, 0)$, polychaetes $(\boldsymbol{\square}, \square)$ Open and closed symbols are for the intensive and non-intensive farm, respectively. Stippled line indicates range $\delta^{13} \mathrm{C}$ values of possible diet for the intensively farmed shrimp. The figure shows that the $\delta^{13} \mathrm{C}$ values of intensively farmed shrimp do not match those of the artificial feed and are similar to those of shrimp from the organic farm

It is not clear whether the artificial feed carbon affects phytoplankton since the plankton from the O-F farm is similar to those from the I-F. The feed certainly does not have an effect on polychaetes, a potential food source for farmed shrimp. These observations lead us to the conclusion that most of the carbon from the feed is deposited in the sediment and inaccessible to the food chain in the pond. Abandonment of ponds is often caused by an unsustainable sedimentation rates, shown here to be by the settlement of feed biomass at the bottom of intensively farmed ponds (Primavera 2006). It has been documented that shrimp can be very specific in their diet choices, such as specifically scraping epiphytes from foliar surfaces of sea grass species (Kitting et al. 1984). We propose that shrimp in these intensive farms might be sampling a food source that is diurnally pumped along with sea water, and therefore acquire a carbon isotope signature more consistent with ocean sources rather than the in situ pond food chain. It is not clear what the 
feed provides that allows for the high density of shrimp in the I-F, since there are several other attributes related to I-F, such as increased flushing and liming, which might increase pond productivity as well.

A detailed evaluation of feeds in actual aqua cultural ponds may elucidate the validity of this practice which brings with it several environmental issues without directly contributing to the increase in shrimp biomass.

\section{Conclusion}

Carbon isotope ratios of shrimp grown in intensive farms, using artificial feed, did not match that of their artificial feed and were similar to shrimp grown in an organic farm without artificial feed. On the other hand, the carbon isotope ratio of the sediments in the intensive farm matches that of the artificial feed and differs from that of the organic farm. This leads us to the conclusion that artificial feed in intensive farming does not feed shrimp efficiently and is mostly deposited in the sediment.

\section{Acknowledgement}

The authors wish to acknowledge the Conselho Nacional de Desenvolvimento Científico e Tecnológico (CNPq - Process number 485043/2006-8) for the financial support.

\section{References}

Burford, M.A., N.P. Preston, T.H. Minh, T.T.T. Hoa, S.E. Bunn, V.M. Fry 2004: Dominant sources of dietary carbon and nitrogen for shrimp reared in extensive rice-shrimp ponds. - Aquaculture Research, 35, pp. 194-203.

Fry, B., C. Arnold 1982: Rapid ${ }^{13} \mathrm{C} /{ }^{12} \mathrm{C}$ turnover during growth of brown shrimp (Penaeus aztecus). Oecologia, 54, pp. 200-204.

Kitting, C.L., B. Fry, M.D. Morgan 1984: Detection of inconspicuous epiphytic algae supporting food web in seagrass meadows. - Oecologia, 62, pp. 145-149.

Primavera, J.H. 2006: Overcoming the impacts of aquaculture on the coastal zone. - Ocean and Coastal Management, 49, pp. 531-546.

World Bank, NACA, WWF, FAO 2002: Synthesis report. World in Progress for Public Discussion. Published by the Consortium, 119 p. 